CURRENT RESEARCH JOURNAL OF HISTORY

(ISSN -2767-472X)

VOLUME 03 ISSUE 01 Pages: 26-29

SJIF IMPACT FACTOR (2021: 5. 505)

OCLC - 1243560778 METADATA IF - 6.458

Crossref do

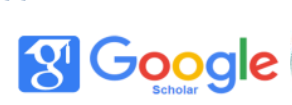

10

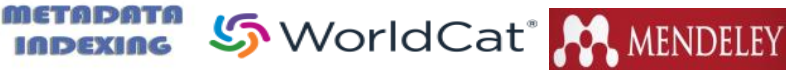

Publisher: Master Journals

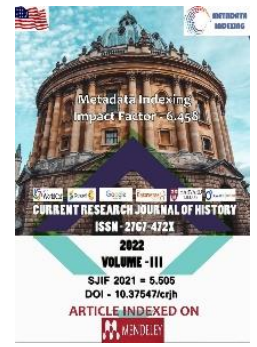

Journal Website: https://masterjournals. com/index.php/crih

Copyright: Original content from this work may be used under the terms of the creative commons attributes 4.0 licence.
Research Article

\section{SOME COMMENTS ON THE COVERAGE OF CHACH HISTORY BY FOREIGN RESEARCHERS}

\author{
Submission Date: January 09, 2022, Accepted Date: January 19, 2022, \\ Published Date: January 29, 2022 \\ Crossref doi: https://doi.org/10.37547/history-crih-03-01-06 \\ Yoqubjon Muhamedov \\ Lecturer, The department of "Archeology", National University of Uzbekistan named after Mirzo Ulugbek, \\ Uzbekistan
}

\title{
ABSTRACT
}

This article discusses some comments on the coverage of Chach history by Foreign researchers. The governing form of Chach rule and the origin of the ruling dynasties in the oasis in the early Middle Age has been reflected in a number of foreign publications, including mainly by the French orientalists E.Shavann, F. Grende, E de la Vessier and the American J.K.Skeff, the Germar researcher Z.Stark, the Hungorian orientalist K.T.Bekvis, the Turkish orientalist and historians Z.V.Togan, E.Esin and E.Ekrem(1).

\section{KEYWORDS}

Chach rule, Foreign researchers, Chinese chronicles.

\section{INTRODUCTION}

They conducted their research mainly on the basis of written sources, in particular, data from Chinese chronicles. They have also been able to shed light on many unresolved issues in the history of the oasis, mainly in the context of the Turkish Khanate. E.Shavann was one of the first to study the history of
Central Asia on the basis of Chinese sources. He also compared the information in Arabic and Persian during the translation of Chinese data on the early medieval political history of the Chach oasis in the monograph "Documents on the History of the western Turks" in the early 20 th century and gave his views on the 
CURRENT RESEARCH JOURNAL OF HISTORY

(ISSN -2767-472X)

VOLUME 03 ISSUE 01 Pages: 26-29

SJIF IMPACT FACTOR (2021: 5. 505)

OCLC - 1243560778 METADATA IF - 6.458

Crossref $d$
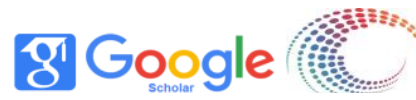

metapmen 5

Publisher: Master Journals

activities of the "tudun" officials sent to Chach by the Khaganate as deputies(2).

\section{THE MAIN RESULTS AND FINDINGS}

T.Grene and E.de la Vassier, compatriots of E.Shavan, conducted their research in relatively recent years. During the analysis of the Sogdian documents of Mount Mugd they translated into French, in particular, a letter document A-14 Ambassador Fatufar to his master, sent to Chach by the Sogdian ruler Devashtich in the $720 \mathrm{~s}$ and focused on the political processes that took place in the oasis in those years(3).

This researchers analyzed the phrases "Chach ruler", :Tudun of Chach", "Khun" found in this document and linked the last two of them with the Turkish Khanate. American researcher J.K.Skeff focused on the reforms of the Turkish Khanate in governing its vassals, mainly based on information from Chinese Chronicles and he tried to shed more light on the issue in the example of Chach's rule. In his opinion the administration of the Khaganate here was more consistent and he acknowledged the special envoys - Tuduns sent by the Khagans, as the deputy was of Turkic origin(4).

The German historian Z.Shtark covered the history of the ancient Turks on the basis of sources in various languages and archeological materials. He briefly dwells on the activities of the rulers of the Ashina dynasty, who originated in the Chach oasis as well as Tuduns. According to him the Turkish Khanate ruled Chach, Fergana and Tokhoristan, also probably Bukhara, by directly appointing representatives of his ruling household(5).

Despite the fact that some foreign researches, in particular(6), J.K.Skeff, E de la Vesseier, F.Grene and Z.Shtark also expressed important new ideas on the political management of the Chach oasis, it can be seen that they were in some one - sided approaches to the ruling dynasties in the oasis(7).

While Z. Stark assessed the occurrence of Turkish titles under vassal rule not as a system, but as a coincidence or a period - specific system, J.K.Skeff noted that the titles of the Chach dynasties were Turkish and the names were non - Turkish. However a number of our researchers noted that the opinion of both researchers was expressed without an in - depth study of the realities of that period and a comprehensive scientific analysis, without comparing data in different languages and no serious attention was paid to numismatic materials and issues such as "fashion of the period" and "non - Turkish names" put forward by them were clarified. In particular, Boboyorov noted that Turkish titles were used in its vassals, just as they were used in the administration of the Khanate during the Turkish Khanate. It they were to be regarded as a system peculiar to the period in which they wrote, any ruler would have used the titles peculiar to the Khaganate in a voluntary manner, that is, in a fragmentary manner, choosing whatever suits him best, regardless of their rank. However this researcher dwelled on the question of "non - Turkish names" and was able to prove from various sources that the names of the 3 tribes found in Chinese Chronicles were also pure Turkish(8).

As mentioned above, E.V.Shavann is one of the first western researchers who applied to from Arabic sources during the translation into French of information from early medieval Chinese chronicles, such as the "Bei shi", "Sui shu", "Tan shu”, on the political history of the Chach oasis.

However, F.Grene and E.de la Vassier, who used these annals and were aware of E.V.Schwann's research, made some mistakes. During the analysis of sogdian documents $A-14$, they give the from Shi - guo Wang 
CURRENT RESEARCH JOURNAL OF HISTORY

(ISSN -2767-472X)

VOLUME 03 ISSUE 01 Pages: 26-29

SJIF IMPACT FACTOR (2021: 5. 505)

OCLC - 1243560778 METADATA IF - 6.458

Crossref do
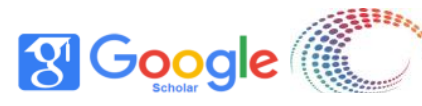

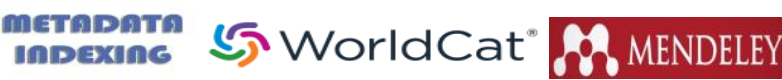

Publisher: Master Journals

"Chach ruler" by dropping theword "tegin" in sentence Shi - guo wang T'ele "Chach ruler Tegin(9)" in full, taking the phrase Shi - guo Fu - Wang "Tudun the Deputy Ruler of Chach"(10). This in turn has led to certain misunderstandings about some historical events. As a result of the researchers' omission of this, a misunderstanding arose as to which title holders were the main dynasties in Chach and which were the opposite, despite the fact that the Chinese source states that Tegin was the ruler of Chach. G.Boboyorov, who drew attention to this issue at the time, wrote that F.Grene and E.de.la Vessier had made a mistake, in fact the main dynasty in Chach was the Tegins and the secondary dynasty was the Tuduns(11). This is confirmed not only by data from Chinese sources (Shi - guo Wang Tele "Chach ruler Tegin" and Shi - guo Fu - Wang - "Tudun the Deputy Ruler of Chach"), but also by the status of "tegin" (prince), "tudun" (deputy) in the hierarchy of titles of Turkish Khanate.

K. I. Bekvis, a major expert on Tibetan sources of the period, covered relatively little - studied topics in the history of the Chach oasis. Aceording to the researches, the name of the Chach assistant ruler found in Chinese chronicles is Turkish and its original is restored in the form of Inal Tudun Kulug(12). In his opinion, the name of the Chach ruler, found in Chinese chronicles in the form of $\mathrm{Ch}-\mathrm{bi}-\mathrm{shi}$, is restored in the form of Chabish, and it is not actually a name, but is associated with the Turkish title "chabish" (chovush). According to the researches, this ruler was the son of Inal (Inai) Tudun Kulug, the second ruler of Chach and was an ally of the Turgas Khagans against China as an assistant to the ruler associated with the Turgash Khanate(13). However, he and his alleys in 751 were captured by the Chinse commander Gao Xijanji, along with the Turgash Khan and Tibetian generals and taken to the capital, Chanian and there he was executed by imperial decree in front of the Kai - Yuan Gate in the capital. After that, the son of the deceased Chach ruler Chabish appealed to Ziyad b. Salikh al-Khuzaina, the head of the Arab garrison in Samarkand against the Chinese. And as a result, in 751 the famous Battle of Talas took place(14). Apparently the victorious Arab armies took Chach under their control, along with the rulers of the oasis who assisted them in this battle, and made him a submissive ruler.

\section{CONCLUSION}

In Short, as a result of acquaintance with some works of some foreign researches on the social and political history of the Chach oasis in the early middle ages, we came to the following conclusion:

- Foreign researches, especially among them French, German, Hungarian, American, etc., have made a significant contribution to the coverage of the history of the Pre - Islamic Chach oasis;

- Their research has been conducted mainly on the basis of written sources in different languages and partly on archeological materials, and is of a nature that sheds considerable light on the abstract aspects of the history of the oasis;

- There are scientific achievements and innovations in the work of foreign researches. It is noticeable that some of the one-sided opinions have also been expressed by them, while the opinions are quite convincing.

\section{REFERENCES}

1. Muhamedov, Y. (2021). The study of control system of chach's oasis by foreign researchers in early middle ages. ACADEMICIA: An International Multidisciplinary Research Journal, 11(3), 2442-2448.

2. Muhamedov, Y. (2021). Reforms Of The Western Turkish Khanate In The Chach 
CURRENT RESEARCH JOURNAL OF HISTORY

(ISSN -2767-472X)

VOLUME 03 ISSUE 01 Pages: 26-29

SJIF IMPACT FACTOR (2021: 5. 505)

OCLC - 1243560778 METADATA IF - 6.458

Crossref doi 81 Google

K

Administration. The American Journal of Social

Science and Education Innovations, 3(02), 133-

140.

3. МУХАМЕДОВ, Ё. (2021). 404

ХУКМДОРЛИГИНИНГ СИЁСИЙ-МАЪМУРИЙ

БОШҚАРУВИ ТАРИХШУНОСЛИГИ. In Uzbek

Conference Publishing Hub (Vol. 1, No. 01, pp. 508-512).

4. Muhamedov, Y. (2021, November). Chach As

The Administrative Center Of The Western Khanate. In International Scientific and

Current Research Conferences (pp. 75-79). 